\title{
Diseases of groundnut in the Southern African Development Community (SADC) region and their management*
}

(Keywords: groundnut, peanut, diseases, IPM, South Africa)

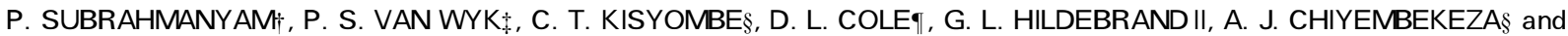

P. J. A. VAN DER NERWE $\ddagger$

$\dagger$ SADC/ICRISAT Groundnut Project, Chitedze Agricultural Research Station, PO Box 1096, Lilongwe, Malawi

$\ddagger$ Oil and Protein Seed Centre, Grain Crops Institute, Private Bag X1251, Potchefstroom 2520, South Africa

$\S$ Chitedze Agricultural Research Station, PO Box 152, Lilongwe, Malawi

- Tobacco Research Board, Kutsaga Research Station, PO Box 1909, Harare, Zimbabwe

II Seed co-op. Company of Zimbabwe, Rattray Arnold Research Station, PO Box CH 142, Chisipite, Harare, Zimbabwe

Abstract. Groundnut is an important food and cash crop in the Southern African Development Community (SADC) region, and is grown largely by smallholder farmers under low input conditions. Constraints are many and varied, both between and within the member states, but diseases are generally regarded as major constraints to groundnut production throughout the region. A large number of fungal, viral, nematode, and bacterial diseases of groundnut have been reported. Most of the diseases are widespread, but only a few of them are economically important on a regional basis. In this paper, the current distribution and economic importance of leaf spots, web blotch, rust, gray mould, pod rots, blackhull, Sclerotinia blight, stem rot, seedling diseases, aflatoxin contamination, rosette, groundnut streak necrosis, pod nematode, and pod scab nematode diseases, and various options (chemical control, host-plant resistance and cultural practices) for their management, are briefly reviewed. Future research needs on groundnut diseases in the region are discussed.

\section{Introduction}

\subsection{The $S A D C$ region}

The Southern AfricanDevelopmentCommunity (SADC) region comprises of 11 member states: Angola, Botswana, Lesotho, Malawi, Mozambique, Namibia, South Africa, Swaziland, Tanzania, Zambia and Zimbabwe. Mauritius joined the SADC as a member state in 1995 when this review was in the final stages of preparation. The region covers an area of c. 6.9 million $\mathrm{km}^{2}$, between the latitudes of near the equator to $35^{\circ} \mathrm{S}$, and between longitudes $11{ }^{\mathrm{W}}$ to $41^{\circ} \mathrm{E}$ (Figure 1). Most of the region is characterized by unimodal summer rainfall from about midNovember to April. Rainfall varies from $<300 \mathrm{~mm}$, poorlydistributed to well-distributed, the annual total being in excess of $1000 \mathrm{~mm}$.

The agricultural sector employs over $70 \%$ of the total labour force in the SADC region, and contributes about $35 \%$ of the Gross National Product, and about 30\% of the foreign exchange earnings. Maize, sorghum, millet, beans and groundnut are important food crops in the region, with maize, the staple food, being by far the largest. An important non-food crop is tobacco, and it is the most important cash crop and foreign exchange earner, in a number of countries in the region.

\subsection{Groundnut production in the SADC region}

Groundnut (Arachis hypogaea L.) is grown from sea level to above $1500 \mathrm{~m}$, but the main areas of production in the region are between 900 and $1200 \mathrm{~m}$ altitude. Groundnut is an important food and cash crop in the region, and is grown largely by smallholder farmers under low input conditions. However, considerable quantities of groundnut are also produced by commercial enterprises in South Africa and Zimbabwe. It is an important legume in large areas of Angola, Malawi, Mozambique, South Africa, Tanzania, Zambia and Zimbabwe. Annual groundnut production in the region is about 0.514 million tonnes from an area of 0.761 million hectares and with productivity

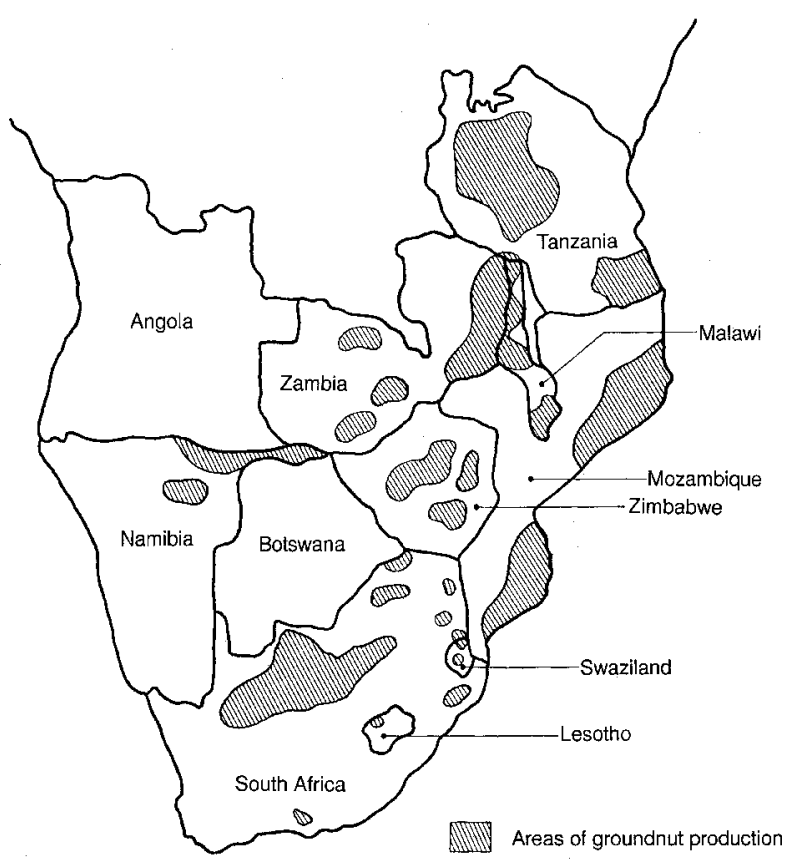

Figure 1. Areas of groundnutproduction in the Southern African Development Community $(S A D C)$ region.

* Submitted as journal article no. 1949 by the International Crops Research Institute for the Semi-Arid Tropics (ICRISAT). 
around $0.70 \mathrm{tha}^{-1}$. In the 1970s and 1980s, groundnut production (-39.5\%), area $(-25.8 \%)$, and productivity $(-19.1 \%)$ have shown declining trends in the region (Reddy et al., 1996). FAO estimates of area, production, and average yields of groundnut in the SADC region in 1993 are shown in Table 1. Average yields are low in marked contrast to yields of over $4000 \mathrm{~kg} \mathrm{ha}^{-1}$ obtained on research stations and by largescale commercial enterprises in the region (Hildebrand, 1975). Constraints are many and varied, both between and within the SADC member states (Nigam and Bock, 1985) but diseases are generally regarded as major constraints to groundnut production in the region (Chiteka et al., 1992).

\section{Diseases of groundnut in the SADC region}

A large number of fungal, viral, nematode and bacterial diseases of groundnut have been reported from the SADC region (Table 2), most of which are widespread, but only a few of them are economically important on a regional basis.

The current distribution and economic importance of selected diseases of groundnut and various options available for their management (chemical control, host-plant resistance and cultural practices), are briefly reviewed. Future research needs on groundnut diseases in the region are also discussed.

\subsection{Fungal diseases}

\subsubsection{Leaf spots}

2.1.1.1. Distribution and economic importance. Early leaf spot (Cercospora arachidicola Hori.) is the most destructive foliar disease of groundnut in the region. The disease is widely distributed and occurs in epidemic proportions in most countries of the region. Annual yield losses of up to $50 \%$ are common over wide areas of the region (Labuschagne and Kloppers, 1988; Bock, 1989). For instance, early leaf spot alone causes a loss of about US $\$ 5.0$ million to the Malawi national income (Babu et al., 1994).

Table 1. Area, production and average yield of unshelled groundnut in the SADC countries in 1993

\begin{tabular}{lccc}
\hline Country & $\begin{array}{c}\text { Area } \\
(000 \mathrm{ha})\end{array}$ & $\begin{array}{c}\text { Production } \\
(000 \mathrm{t})\end{array}$ & $\begin{array}{c}\text { Yield } \\
\left(\mathrm{kg} \mathrm{ha}^{-1}\right)\end{array}$ \\
\hline Angola & $35 \mathrm{~F}$ & $18 \mathrm{~F}$ & 500 \\
Botswana & $2 \mathrm{~F}$ & - & 159 \\
Lesotho & - & - & - \\
Malawi & 61 & $59^{*}$ & 963 \\
Mozambique & $218^{*}$ & $84^{*}$ & 385 \\
Namibia & - & - & - \\
South Africa & $160^{*}$ & $174^{*}$ & 1087 \\
Swaziland & $2 \mathrm{~F}$ & $3 \mathrm{~F}$ & 1304 \\
Tanzania & $110 \mathrm{~F}$ & $70 \mathrm{~F}$ & 636 \\
Zambia & $68 \mathrm{~F}$ & 42 & 622 \\
Zimbabwe & $105 \mathrm{~F}$ & 64 & 614 \\
SADC Region & & & 697 \\
Africa & 761 & 4956 & 816 \\
\hline
\end{tabular}

Source: FAO Production Yearbook 1993.

$\mathrm{F}=\mathrm{FAO}$ estimates; ${ }^{*}=$ unofficial figure.
Late leaf spot (Phaeoisariopsis personata (Berk. \& Curt.) v. Arx) is also widely distributed, mainly in low altitude areas, but is economically important only in the lake shore, southern, and northern areas of Malawi, in coastal southern Tanzania, Southern Mozambique, Swaziland and Zambia. Late leaf spot usually occurs together with rust (Puccinia arachidis Speg.) in several parts of the region. Early and late leaf spots and rust commonly occur together in many production systems in the region. The predominance of each of these foliar diseases is largely dependent on climatic conditions.

\subsubsection{Management}

2.1.1.2.1. Chemical control. Although both early and late leaf spots can be easily controlled by certain fungicides, this practice is not economically feasible for smallholder farmers with limited financial and other resources. However, control of leaf spots using fungicides is successfully practised by commercial farmers in the region (e.g. South Africa and Zimbabwe).

Considerable effort has been directed at fungicidal control of early leaf spot in Malawi, South Africa, Tanzania, Zambia and Zimbabwe. Research in Zimbabwe on timing and number of applications of chlorothalonil or a mixture of benomyl and mancozeb, has led to effective management of the early leaf spot and web blotch (Didymella arachidicola (Chock.) Taber, Pettit \& Philley) disease complex on irrigated groundnuts (Cole, 1981). However, fungicide application to rainfed groundnut is considered to be uneconomic in Zimbabwe.

For many years in Malawi efforts have been directed at fungicidal control of early leaf spot (Mughogho, 1969; Mercer, 1974; Kisyombe, 1980, 1987a, 1987b). In the mid-1960s, sulphur dusting and spraying of benzimidazole compounds were recommended for the control of the disease. During the 1970s, an extensive research programme was initiated using various new fungicides including bitertanol, chlorothalonil, captafol, copper hydroxide, propiconazole, zineb and a mixture of benomyl and mancozeb. It was found that leaf spot control was very effective when chlorothalonil was applied before the onset of disease and subsequently at $14 \mathrm{~d}$ intervals. Six applications on long-duration varieties and four applications on short-duration varieties were recommended. In the 1970s, the early leaf spot pathogen developed resistance to some systemic fungicides (benomyl, thiabenzole and carbendazim) and they became ineffective. In the early 1980s, chlorothalonil was recommended for controlling early leaf spots (Kisyombe, 1980). Unfortunately, this recommendation was not cost effective (Mwenda and Cusack, 1989) probably because of increased cost of the chemical, spraying machines, and low producer price for the product. In recent years, strategically timed single applications of fungicides (labilite and chlorothalonil) were found to be very effective and economical in Zambia (Kannaiyan et al., 1989a) and in Malawi (Hildebrand and Bock, 1990). Further investigations carried out during the 1990/91 to $1993 / 94$ crop seasons in Malawi, using either one spray or two sprays of chlorothalonil, indicated that fungicidal control was economical in seasons with normal rainfall. However, in dry seasons (e.g. 1993/94 crop season), it was not economical (Subrahmanyam, unpublished) and on-farm evaluation of the economics of fungicidal control is currently underway in Malawi. In Zimbabwe, a minimum of three sprays was required to improve yield significantly (Cole, unpublished). 
Table 2. A check list of diseases of groundnut in the SADC region

\begin{tabular}{l} 
Disease \\
\hline Fungal diseases \\
Foliar diseases \\
Alternaria leaf blight \\
Anthracnose \\
Leaf spots \\
Early leaf spot \\
Late leaf spot \\
Melanosis \\
Pepper spot and leaf scorch \\
Phoma leaf spot \\
Phomopsis leaf blight \\
Phyllosticta leaf spot \\
Powdery mildew \\
Rhizoctonia leaf blight \\
Rust \\
Scab \\
Sclerotium leaf spot \\
Web blotch \\
Btem, root and pod diseases \\
Botrytis gray mould \\
Charcoal rot \\
Concealed damage \\
Fusarium wilt \\
Pod rots
\end{tabular}

Root rot

Sclerotinia blight

Stem rot

Verticillium wilt

Seed and seedling diseases

Preemergence seed

and seedling rots

Crown rot/collar rot

Yellow mold/aflaroot

Bacterial diseases

Bacterial leaf spot

Bacterial wilt

Diseases caused by viruses and mycoplasmas

Peanut mottle

Groundnut rosette, chlorotic rosette, and green rosette

Bud necrosis

Crinkle and leaf roll

Groundnut streak necrosis

Witches' broom

Causal organism

Distribution

Alternaria tenuis Auct.

Colletotrichum gloeosporioides (Penz.) Penz. \& Sacc. C.capsici (Syd.) But. \& Bis

Cercospora arachidicola Hori

Phaeoisariopsis personata (Berk. \& Curt.) v. Arx

Stemphylium botryosum Wallroth

Leptosphaerulina crassiasca (Sechet) Jackson \& Bell

Phoma eupyrena Sacc.

P. glomerata (Corda). Wr. \& Hoch. Phomopsis sp.

Phyllosticta arachidis-hypogaea V. Rao

Phyllosticta sp.

Erysiphe polygoni

Rhizoctonia solani Kuhn

Puccinia arachidis Speg.

Sphaceloma arachidis Bit. \& Jenk.

Sclerotium rolfsii sacc.

Didymella arachidicola (Chock.) Taber, Pettit \& Philley

Chalara elegens Nag Raj \& Kendrick Macrophomina phaseolina (Tassi) Goid.

Botrytis cinerea Pers. ex Fries

Macrophomina phaseolina (Tassi) Goid.

Macrophomina phaseolina (Tassi) Goid. Fusarium spp. Fusarium oxysporum Schl. em Sny. \& Hans.

Rhizoctonia solani Kuhn

Macrophomina phaseolina (Tassi.) Goid.

Sclerotium rolfsii Sacc.

Fusarium spp.

Pythium spp.

Rhizoctonia solani Kuhn

Sclerotium rolfsii Sacc.

Fusarium spp.

Sclerotinia sclerotiorum (Lib.) de Bary

S. minor Jagger

Sclerotium rolfsii Sacc. Verticilliumsp.

Rhizopus spp.

Fusarium spp.

Pythium spp.

Rhizoctonia solani Kuhn

Macrophomina phaseolina (Tassi). Goid.

Sclerotium rolfsii Sacc.

Aspergillus niger van Tieghem

A. flavus Link ex Fries.

A. parasiticus Speare

Aspergillus niger van Tieghem

Aspergillus flavus Link ex Fries.

A. parasiticus Speare

Unidentified

Burkholderia solanacearum (E.F.Smith)

Peanut mottle virus (PMN) (potyvirus group)

Groundnut rosette virus (GRV) and its satellite RNA Groundnut rosette assistor virus (RAV, a luteovirus) Tomato spotted wilt virus (TSWV) (phytobunya virus) Cowpea mild mottle virus (CMMN) (carlavirus group) Sunflower yellow blotch virus (luteovirus) Phytoplasma-like organism
$\mathrm{MZ}, \mathrm{SA}, \mathrm{ZW}$

$\mathrm{MW}$

TZ

Regional

Regional

AN (?)

MN, MZ, SA, SZ, ZA, ZW

$\mathrm{MW}$

MW

ZA

$M W, M Z, S Z, Z W$

ZA, ZW

$\mathrm{TZ}, \mathrm{MM}(?)$

MW

Regional

SZ(?)

$\mathrm{MW}$

AN, LE, MW, SA, SZ, ZA, ZW

SA

MN, SA

AN, MW, SA, TZ, ZW

MW, SA

MW

MN, SA, ZA

Regional

MN, SA, ZA

SA, ZW

SA

AN, LE, MW, MZ, SA, SZ, ZW

TZ

Regional

Regional

Regional

ZW

AN, MN, SA, SZ, ZA, ZW

AN, MN, MZ, SA, ZA, ZW

Regional

TZ, MW, SA

ZA, MW

MW, MZ, SA, TZ, ZA, ZW

MW, SA 
Table 2. Continued

\begin{tabular}{|c|c|c|}
\hline Disease & Causal organism & Distribution \\
\hline \multicolumn{3}{|l|}{ Nematode diseases } \\
\hline \multirow[t]{4}{*}{ Root-knot } & Meloidogyne arenaria (Neal) Chitwood & MW, ZW \\
\hline & M. hapla Chitwood & $\mathrm{MW}, \mathrm{ZW}, \mathrm{SA}$ \\
\hline & M. javanica (Treub) Chitwood & $\mathrm{MN}, \mathrm{ZW}, \mathrm{SA}$ \\
\hline & M. incognita & SA \\
\hline Root-lesion & Pratylenchus brachyurus (Godfrey) Filipjev \& Sch. Stekh & $\mathrm{MW}, \mathrm{SA}, \mathrm{ZW}$ \\
\hline Pod nematode & Ditylenchus africanus & SA \\
\hline Pod scab nematode & Tylenchorhynchus breviliniatus & SA \\
\hline \multicolumn{3}{|c|}{ Other plant-parasitic nematodes associated with groundnut: } \\
\hline & H. nigeriensis Sher & $\mathrm{MW}$ \\
\hline & Helicotylenchussp. & MW \\
\hline & Pratylenchus sp. & $\mathrm{MW}$ \\
\hline & Radopholus similis (Cobb) Thorne & $\mathrm{MW}$ \\
\hline & Scutellonemasp. & $\mathrm{MW}$ \\
\hline & Xiphinema spp. & MW \\
\hline \multicolumn{3}{|c|}{ Phanerogamic root parasites } \\
\hline \multirow[t]{2}{*}{ Witch weeds } & Alectra vogelii Benth. & AN, MN, MZ, ZA, ZW, SW \\
\hline & Striga gesnerioides (Wild.) Vatke (?) & NR \\
\hline
\end{tabular}

$\mathrm{AN}=$ Angola, $\mathrm{LE}=$ Lesotho, $\mathrm{MV}=$ Malawi, $\mathrm{MZ}=$ Mozambique, $\mathrm{SA}=$ South Africa, $\mathrm{SZ}=$ Swaziland, $\mathrm{TZ}=\mathrm{Tanzania}, \mathrm{ZA}=\mathrm{Zambia}, \mathrm{ZW}=\mathrm{Zimbabwe}$, and Regional $=$ occurs in all SADC countries.

In South Africa, a wide range of fungicides has been evaluated (Strauss and van Wyk, 1995). A mixture of carbendazim and thiophanate methyl was found effective in controlling leaf spots, web blotch and grey mould. Spray schedules are normally adjusted according to weather conditions. During wet seasons, two or three applications of systemic fungicides may be required, while during dry seasons, a single spray of a systemic fungicide or even one or two applications of the contact fungicide chlorothalonil will give satisfactory control.

2.1.1.2.2. Host-plant resistance. All groundnut cultivars grown in the region are susceptible to leaf spots. Until recently, sources of groundnut with adequate levels of resistance have not been available (Bock, 1989) and germplasm lines identified as resistant to early leaf spot in other countries were found to be susceptible in Malawi (Subrahmanyam, 1983). Hence progress in breeding high-yielding groundnut genotypes with resistance to early leaf spot has been slow.

In recent years, the ICRISAT groundnut team located at Chitedze Agricultural Research Station near Lilongwe, Malawi developed a simple and effective technique for field screening for resistance against early leaf spot. A large collection of South American, African and Asian germplasm accessions, breeding lines and interspecific derivatives was screened for resistance and several high-yielding genotypes with resistance to the disease have been identified.

Evaluation of germplasm and breeding lines for resistance against late leaf spot has been carried out in the region (Rao and Masina, 1987; Kannaiyan et al., 1987). Lines identified as resistant to late leaf spot at ICRISAT Asia Center, India (Subrahmanyam et al., 1989) were also resistant when tested in the region. Recently, several high-yielding agronomically superior breeding lines, with resistance to rust and late leaf spot developed at ICRISAT Asia Center, were evaluated in Malawi. Resistance to rust and late leaf spot diseases in these lines has been confirmed and several high-yielding lines have been selected for on-farm evaluation in the country (Chiyembekeza and Subrahmanyam, unpublished).

2.1.1.2.3. Cultural practices. Several workers have investigated the effects of various cultural practices on the severity of leaf spots. Since both leaf spot pathogens persist from season to season via infected crop debris, removal or burial of crop residues may be beneficial in delaying disease onset. However, these crop sanitation measures may not be practical to smallholder farmers in the region. It is unlikely that volunteer plants play a major role in perpetuation of the leaf spot pathogens in Malawi (Mughogho, 1969), or in other countries of the region because of livestock grazing during the off-season.

Crop rotation has been shown to provide partial control of leaf spots (Hemmingway, 1954; Rothwell, 1962; Mughogho, 1969). Subrahmanyam et al. (1994a) reported that disease onset was very early (before flowering), and development was most severe in fields where groundnut followed groundnut. However, in groundnut which followed either maize or pasture, the disease development was slow and less severe. Crop rotation may not be a useful option in some countries because of the small land holdings.

Delayed sowing is reported to increase the severity of leaf spots and reduce the yields in Tanzania (Simons, 1985; Lyimo and Kangalawe, 1991) and in Malawi (Subrahmanyam et al., 1994a). However, in Zambia, the severity of leaf spots was found to be higher in early sown (late November or early December) groundnut than in late sown (late December) groundnut (Kannaiyan et al., 1989a). Early sowing has several other agronomic benefits such as utilization of soil moisture and fertilizers.

In Zambia, disease severity on groundnut intercropped with maize, pigeonpea, sorghum, sunflower, or cotton was not markedly different from that of sole groundnut crops (Kannaiyan et al., 1989a). In Malawi, the severity of early leaf spot was not markedly different between sole and intercropped groundnut at 
Chitedze, but at Makoka, the severity of early leaf spot and rust was lower on intercropped groundnut than on sole crop (Subrahmanyam, 1991). In Tanzania, disease severity was found to be higher in intercropped groundnuts than in sole groundnuts (Lyimo and Kangalawe, 1991). Mpiri (1991) reported an interaction between groundnut genotype and the ratio of crop components in intercropping, affecting the severity of leaf spots in Tanzania.

Plant densities ranging from 44000 to 222000 plants ha $^{-1}$ showed no marked effects on leaf spots severity in Zambia (Kannaiyan et al., 1989a). However, Farrell et al. (1967) reported an inverse relationship between in-row spacing of plants and intensity of leaf spots in Malawi.

Late leaf spot was found to be less severe in cultivar mixtures than in the individual components in Tanzania. Cultivar mixtures suffered less from late leaf spot and yielded higher than the individual cultivars grown in pure stands (Lyimo and Kangalawe, 1991).

The ICRISAT groundnut team is currently investigating the suitability of integrating low input strategies including utilization of genetic resistance, single applications of chlorothalonil, and suitable agronomic practices as crop rotation, and time of sowing to lessen the risk of leaf spot severity and minimize yield reduction (Subrahmanyam, 1991).

\subsubsection{Web blotch}

2.1.2.1. Distribution and economic importance. Web blotch (Didymella arachidicola (Chock.) Taber, Pettit \& Philley) has been reported in Angola, Lesotho, Malawi, South Africa, Swaziland, Zambia, and Zimbabwe (Subrahmanyam et al., 1994b). Web blotch is one of the most important foliar diseases of groundnut in Zimbabwe, where it occurs mainly on longseason crops (Cole, 1981, 1985). Yield losses of about 40\% due to combined attacks of web blotch and leaf spots have been reported in Zimbabwe (Hildebrand, 1987). In South Africa, the disease has been reported since 1946 in the Vaalharts region (Kloppers and Labuschagne, 1989) and was most devastating during the late 1960 s and early 1970s, largely due to the use of fungicides which were inefficient against web blotch (Pauer, 1979; Swanevelder, 1982).

\subsubsection{Management}

2.1.2.2.1. Chemical control. In Zimbabwe, chlorothalonil or a mixture of mancozeb plus benomyl was moderately effective against web blotch (Cole and Chingombe, 1981). However, under severe disease pressure, none of these fungicides was very effective. Recently, Cole (1986) recommended procymidone for the control of web blotch but early leaf spot control was less satisfactory. Cole (unpublished) found tebuconazole was also very effective in controlling web blotch. However, where both early leaf spot and web blotch occur, the most effective fungicide against web blotch are not necessarily the ones recommended because a fungicide that controls both diseases to some extent makes economic sense. Web blotch appears some 2 to 3 weeks later than early leaf spot, and not on leaves infected with early leaf spot. If early leaf spot is controlled from first appearance, web blotch levels rise significantly compared to plants on which early leaf spot control is delayed (Cole, 1981). Early leaf spot is very easily controlled by a range of fairly inexpensive fungicides, whereas those that control web blotch tend to be more expensive. Cole (1981) found that by delaying the first sprays until early leaf spot was seen on all plants, the colonization of leaves by web blotch was suppressed and it could then be controlled by the less effective but cheaper fungicides.

2.1.2.2.2. Host-plant resistance. In Zimbabwe, several hundred germplasm lines were screened for web blotch resistance under field conditions during the 1976/77 crop season. Three genotypes showed a high degree of resistance; PI 274190 (60/ 66), Bambey 48-14 (367/63) and Bambey 48-21 (369/63) (Hildebrand, 1981). PI 274190 exhibited the highest degree of resistance but was not agronomically acceptable. Several breeding lines, including C 346/5/8, C 347/5/6 and P 105/3/7, with high levels of resistance to web blotch, have been bred in Zimbabwe (Chiteka, 1984; Hildebrand, 1984, 1985). Most of the selections from the cross (PI $274191 \times P I 274203$ ) showed an unusual reaction to web blotch, where leaflets became extensively affected by a net-like blotch, often covering most, if not all, the adaxial surface (Hildebrand, 1983). Microscopic examination revealed the fungus to be confined to the area just beneath the epidermis. It is not clear whether this is an expression of hypersensitivity, but these genotypes did not defoliate rapidly, and produced high yields. Chiteka (1984) has reported good resistance to web blotch and grey mould (Botrytis cinerea Pers. ex Fries) in the breeding line $P$ 105/3/7 ((PI 261911 XPI 262092) XEgret).

Hildebrand (unpublished) evaluated several accessions of wild Arachis species for resistance against web blotch under field conditions in Zimbabwe. A. duranensis (PI 219823), A. burkartii (PI 338325), A. pusilla (PI 262133), and Arachis sp. (PI 338279) were found to be resistant to web blotch.

2.1.2.2.3. Cultural practices. The web blotch pathogen can survive in infected crop residues, or on volunteer groundnut plants. Pycnidia and pseudothecia develop on fallen leaves in the field, and provide initial inoculum to infect subsequent groundnut crops. Crop rotation may be useful in eliminating the primary sources of inoculum.

\subsubsection{Rust}

2.1.3.1. Distribution and economic importance. Rust (Puccinia arachidis Speg.) was first recorded in Africa in Rhodesia (now Zimbabwe) in 1974 (Rothwell, 1975). Rust occurs sporadically in several countries of the region, mainly in low altitude areas (Cole, 1987), and is economically important in the lake shore and southern areas of Malawi, coastal southern Tanzania, southern Mozambique, Swaziland and Zambia. In South Africa, rust occurs mainly in Northern Province, Mpumalanga and Northern KwaZulu-Natal areas and only occurs rarely further south of the country (Swanevelder, 1985).

Yield losses are substantial when the crop is attacked by both rust and late leaf spot. From a two year study in Tanzania, Simons (1985) estimated yield losses ranging from 34 to $44 \%$ due to combined attacks of rust and leaf spots. Yield losses due to rust alone ranged from 20 to $25 \%$. In Malawi, yield losses range from 25 to $50 \%$ due to combined attacks of rust and late leaf spot (Subrahmanyam, unpublished). 


\subsubsection{Management}

2.1.3.2.1. Chemical control. Chlorothalonil, bitertanol, captafol, copper hydroxide, propiconazole, mancozeb, zineb, and a mixture of benomyl and mancozeb are effective against both rust and leaf spots in Malawi. The structurally related fungicides benomyl and carbendazim are effective against leaf spots but ineffective against rust. Tridemorph is effective against rust but not against leaf spots. It is obvious that any fungicide treatment applied for control of rust must also be effective against leaf spots, as the diseases frequently occur together.

2.1.3.2.2. Host-plant resistance. In recent years, several high-yielding agronomically superior breeding lines, with high levels of resistance to rust and with moderate levels of resistance to late leaf spot developed at the ICRISAT Asia Center, were evaluated in the region. Resistance to rust and late leaf spot in these lines has been confirmed and several high-yielding lines have been identified. In Swaziland, ICG (FDRS) 4 has been found to be the most promising with a yield advantage of about $45 \%$ over Natal Common and is being considered for release. In Malawi, ICGV 93197 was found to be the most promising genotype in on-farm trials during the 1993/ 94 growing season (Chiyembekeza and Subrahmanyam, unpublished).

2.1.3.2.3. Cultural practices. Rust spores survive for less than a month in infected crop debris. A clear break in time between successive groundnut crops is recommended to reduce or to eliminate viable inoculum (Subrahmanyam and McDonald, 1983). In the SADC region, groundnut is grown mainly during the rainy season, but rust may survive in the dimba or off-season groundnut crops and carry-over and dissemination of rust spores over long distances is possible. It is unlikely that volunteer groundnut plants play an important role in perpetuation of rust pathogen in the region because of livestock grazing during the off-season. Wind-borne inoculum seems to play an important role in the spread of groundnut rust over long distances in the region.

\subsubsection{Grey mould}

2.1.4.1. Distribution and economic importance. Grey mould (Botrytis cinerea Pers. ex Fries) occurs sporadically in Angola, Malawi, South Africa, Tanzania and Zambia but the disease is economically important mainly on long-season crops in the cooler (below $20^{\circ} \mathrm{C}$ ) and wetter areas of Zimbabwe and South Africa. The disease has become increasingly severe in dense canopies where effective leaf spot control has been achieved with fungicides ineffective against the grey mould pathogen.

2.1.4.2. Management. Procymidone is effective against grey mould in Zimbabwe (Cole, 1986). Fungicide formulations containing carbendazim or thiophanate methyl are effective in South Africa (Labuschagne et al., 1990; Strauss and van Wyk, 1995). Recently, a number of genotypes with resistance to grey mould have been identified in Zimbabwe (Chiteka, 1990). Chiteka (1984) reported good levels of resistance to both grey mould and web blotch in the breeding line $P$ 105/3/ 7 ((PI 261911 XPI 262092) XEgret).

\subsubsection{Pod rots}

2.1.5.1. Distribution and economic importance. Pod rots caused by a variety of soil-borne fungi (Rhizoctonia solani Kuhn., Macrophomina phaseolina (Tassi.) Goid, Sclerotium rolfsii Sacc., Sclerotinia minor Jagger, Pythium spp., and Fusarium spp.) occur in all countries in the region. In Malawi, pod rot is serious in low-lying areas especially in soils which become waterlogged in the rainy season. Pod rot is considered to be economically important in South Africa and Zimbabwe and contributes to poor seed quality. In some areas of South Africa, S. rolfsii accounts for over $50 \%$ of downgraded seed and is widely associated with the pod nematode Ditylenchus africanus.

2.1.5.2. Management. Traditional crop rotation has been reported to be ineffective in controlling pod rots. However, in Malawi, fields where groundnut had been grown for several years in succession had significantly more pod rots caused by $S$. rolfsii and $R$. solani than did rotated or fallowed fields (Subrahmanyam, unpublished). Cultivation in well-drained soil will reduce pod rot severity. Delayed harvesting increases pod rot severity and seed quality in Malawi (Subrahmanyam, 1983) and in Zambia (Kelly, 1985). Control of leaf spots reduced the incidence of pod rots in Malawi (Mercer, 1978) and in Zimbabwe (Cole, 1981).

\subsubsection{Blackhull}

2.1.6.1. Distribution and economic importance. Blackhull (Chalara elegans Nag Raj \& Kendrick) is restricted to irrigated areas of the Vaalharts region of South Africa and was responsible for a drop in production from 30000 tonnes during the mid-1970s to about 4000 tonnes in 1985. The disease was first recognized in the early 1970 s.

2.1.6.2. Management. The cultivars Norden and Harts are resistant to blackhull at low to moderate inoculum levels and are now recommended for cultivation in the Vaalharts region of South Africa (van der Merwe and Swanevelder, 1988a, 1988b).

\subsubsection{Sclerotinia blight}

2.1.7.1. Distribution and economic importance. Sclerotinia blight (Sclerotinia minor Jagger) occurs in the Northern Cape Province of South Africa where it is especially serious on the runner cultivar Norden. The disease is mostly restricted to localized production units in the irrigation areas where it was probably introduced by infected sweet peas. The disease is especially serious in fields where rotation is not practised (van Wyk, unpublished).

2.1.7.2. Management. Several cultivars are less susceptible than the runner type Norden. A high level of resistance was observed in the cultivar Robbie (van der Merwe and Joubert, 1995). Deep ploughing, avoiding sweet peas in the rotation, and sowing less susceptible cultivars was found to be useful in South Africa (van der Merwe and Joubert, 1995). 


\subsubsection{Stem rot}

2.1.8.1. Distribution and economic importance. Stem rot caused by Sclerotium rolfsii Sacc. is one of the most widespread diseases of groundnut in the region. In South Africa, its widespread occurrence relates to the common practice of mulching to restrict wind damage on sandy soils. Furthermore, alternative hosts of the pathogen such as sunflower (Helianthus annuus) are widely grown in rotation with groundnuts and maize. Stem rot is rarely serious under irrigation. However, its occurrence coincides with prolonged wet periods during the latter part of the season. Its severity is also enhanced when plants have been earthed-up mechanically or during windy conditions. Sporadic, but extensive outbreaks occur on commercial farms in Zimbabwe (Cole, unpublished). Stem rot is not economically important in other countries in the region.

2.1.8.2. Management. Deep ploughing, avoiding earthing-up operations, and rotation with grasses are currently recommended in South Africa.

\subsubsection{Seedling diseases}

2.1.9.1. Distribution and economic importance. Seedling diseases caused by a variety of seed- and soil-borne fungi (Aspergillus niger van Tieghem, A. flavus Link ex. Fr., Rhizopus spp., Rhizoctonia solani Kuhn, Macrophomina phaseolina (Tassi.) Goid, Pythium spp. and Fusarium spp.) are widespread and economically important in almost all countries in the region. Reduction in plant stand due to seedling diseases is substantial if seed protectant chemicals are not used. However, the yield losses associated with seedling diseases are not well quantified in many countries in the region.

2.1.9.2. Management. Seedling diseases can be effectively and economically controlled by seed dressing with fungicides. Adequate information is available on the use of fungicides (e.g. thiram, captan, mancozeb, benomyl) in the region (Mercer and Kisyombe, 1978; Mayeux and Maphanyane, 1989; Kannaiyan et al., 1989b). Only high quality seed should be used for planting. Deep planting of seed should be avoided as etiolated seedlings are more susceptible to infection. Deep plowing of fields and crop rotation are useful in reducing the incidence of seedling diseases. Since seedling diseases can be controlled very effectively and economically using fungicidal seed dressing, identification and utilization of host-plant resistance is not warranted at the present time.

\subsubsection{Aflatoxin contamination}

Contamination of groundnut with aflatoxins, the secondary toxic metabolites produced by fungi of the Aspergillus flavus group, is a serious quality problem in the region (Cole, 1991), but it is not considered to be a serious problem in Malawi (Kisyombe, 1989). $A$. flavus may invade groundnut seeds before harvest (Cole and Masuka, 1988), during post-harvest drying, and during storage if seeds are rewetted. Pre-harvest aflatoxin contamination is important under drought-prone conditions while post-harvest contamination is significant under wet and humid conditions (Mehan, 1987).
A considerable amount of information has been assembled for the region and elsewhere on the influence of environmental factors, crop production, and produce handling procedures on seed infection and aflatoxin contamination (Du Toit, 1977; McDonald, 1989).

2.1.10.1. Management. The following measures are recommended (see Mehan, 1987; McDonald, 1989):

- prevention of drought stress by supplemental irrigation, wherever possible, during the later part ( $4-5$ weeks) of the crop season,

- avoiding mechanical damage to the crop, particularly during cultivation, harvesting, and subsequent storage,

- cultivation of resistant varieties,

- harvesting at optimum maturity. Cole and Masuka (1988) found that although groundnuts were contaminated preharvest (19\% samples had aflatoxin), there was no further deterioration in storage at moisture levels below $6 \%$.

- drying of pods to a safe moisture level (8\%), and

- storage of produce at low temperature and low humidity, and insect-free conditons.

There is a need to educate farmers and other people handling groundnuts and groundnut products in these simple cultural practices tailored to suit the particular country's situation for effective reduction in aflatoxin contamination.

\subsection{Virus diseases}

\subsubsection{Groundnut rosette}

2.2.1.1. Distribution and economic importance. Groundnut rosette is apparently restricted to the African continent, south of the Sahara and it is recognized as one of the major constraints to groundnut production in the SADC region (Nigam and Bock, 1985). Both chlorotic rosette and green rosette occur in the region, but chlorotic rosette is the most prevalent and destructive. Groundnut rosette is caused by a complex of three agents, groundnut rosette virus (GRV) and its satellite RNA, and groundnut rosette assistor virus (GRAV) (Reddy et al., 1985). The disease is transmitted by aphids (Aphis craccivora Koch.).

Although disease epidemics are sporadic, they cause yield losses approaching $100 \%$. The occurrence and severity of groundnut rosette in the region varies considerably. For instance, groundnut rosette assumed epidemic proportions in Malawi in 1982/83 when incidences ranging from 40 to $100 \%$ were recorded in farmer's fields (Subrahmanyam, 1983). Rosette was also found to be serious at Chipata in eastern Zambia and on late-sown crops at Chihuri in Zimbabwe during 1982/83. In Malawi, rosette incidence then remained relatively low until 1988/89 with occasional out-breaks (average incidence ranging from 15 to $58 \%$ ) in experimental fields. In 1991/92, the disease incidence was over $90 \%$ on late sown groundnuts, but was negligible $(<1 \%)$ on early sown groundnut crops at Chitedze. After a gap of several years, rosette again occurred in epidemic proportions in Malawi and Zambia during the 1994/ 95 growing season. The disease was especially serious in the 
Lilongwe-Kasungu-Mchinji triangle and in the Eastern Province of Zambia. Systematic disease surveys conducted in over 140 farmers' fields in central Malawi revealed an average disease incidence of $51 \%$ (Subrahmanyam et al., 1996). The reasons for these fluctuations have not been fully elucidated.

\subsubsection{Management}

2.2.1.2.1. Chemical control. Management of groundnut rosette by insecticidal control of the vector has been known since the mid-1960s. However, chemical control is not economically or practically feasible for smallholder farmers in the region, because it requires careful monitoring of the vector. With increased concern for ecological preservation, this practice now has further disadvantages.

2.2.1.2.2. Host-plant resistance. Pioneering research on development of groundnut cultivars with resistance to rosette has been carried out in West Africa. Sources of resistance to rosette were first discovered in 1952 in Senegal in germplasm lines originating from the frontier region between Burkina Faso and Còte d'Ivoire. Resistance is effective against both chlorotic rosette and green rosette and is governed by two independent recessive genes. These sources formed the basis for rosette resistance breeding programmes throughout Africa and have contributed to the development of several high-yielding, agronomically acceptable groundnut genotypes (e.g. RMP 12, RMP 91, KH 241-D and RG 1).

Progress in the utilization of genetic resistance in the SADC region has been limited in the past, but the leading effort is the NARS in Malawi. The rosette-resistant cultivar RG 1 was released in Malawi but was not readily accepted by farmers because of its long duration and difficulty in shelling. Most of the rosette-resistant cultivars released to date are late maturing and are not suitable for many locations in the region where the rainy season is short.

The ICRISAT groundnut team has developed a technique for field screening for resistance to rosette (Bock, 1987) which now permits screening of large numbers of germplasm lines, segregating populations and breeding lines. During the 1990/ 91 to 1994/95 growing seasons, over 6600 South American, African and Asian germplasm lines, and 160 interspecific derivatives were systematically evaluated for rosette resistance. Over 100 rosette-resistant germplasm accessions, including 16 early maturing Spanish types, have now been identified (Subrahmanyam et al., 1996). Resistance to groundnut rosette was identified for the first time in non-West African genotypes, so these sources should be useful in broadening the genetic base of resistance.

Considerable progress has been made at the SADC/ ICRISAT Groundnut Project in developing rosette-resistant groundnut genotypes. A large number of high-yielding, agronomically acceptable, virginia bunch genotypes have been developed. Fifteen (ICGV-SMs 88709, 88710, 88711, 88734, 88737, 88762, 89749, 89751, 89757, 89786, 89790, 90703, 90704, 90713 and 91701$)$ of these lines were evaluated in Regional Trials from $1989 / 90$ to $1993 / 94$ and ICGV-SM 90704 was identified for release in Malawi (Chiyembekeza et al., 1996). In addition, eight short-duration rosette-resistant cultivars (ICGVSMs 93523, 93524, 93525, 93535, 93557, 93561, 94585, and
94587) have been developed and are being evaluated for yield and adaptation at selected locations in Malawi.

2.2.1.2.3. Cultural practices. Abundant information is available on the control of groundnut rosette by cultural practices which manipulate sowing date and plant density. Several researchers have conclusively demonstrated that groundnut rosette can be effectively reduced when groundnut is sown early in the season and at high population densities (Gibbons et al., 1966; Davies, 1976; Farrell, 1976a, 1976b). Although, Bock (1987) observed the presence of aphids at crop emergence, early sowing will avoid peak periods of aphid flight activity resulting in low disease incidence (Farrell, 1976a, 1976b). This has been supported by further research in recent years in the SADC region. In Zambia, late planted groundnuts with poor plant stands showed higher rosette incidence (36-85\%) than the earlier planted crops with full stand (2-6\%) (Sandhu et al., 1985). Subrahmanyam (1983) reported that the disease incidence was higher (97.3\%) in late sown (mid January) groundnut than in early sown (early December) groundnut (22.1\%) in Malawi. Rosette incidence was found to be low in the population range of 90000 to 120000 plants ha $^{-1}$ in Malawi (Ngwira, 1985). Aphids were more abundant in low plant populations (222 000 plants $\mathrm{ha}^{-1}$ ) than in high plant populations (333000 plants ha ${ }^{-1}$ ) in Mozambique (Ramanaiah et al., 1989). Interestingly, during the 1994/95 growing season in Malawi, both early- and late-sown groundnuts were severely affected by rosette when there was drought stress during the seedling stage (Subrahmanyam, unpublished).

Eradication of volunteer groundnut plants and groundkeepers was suggested to be useful in preventing the perpetuation of virus inoculum during the off-season (Reddy, 1984). However, Farrell and Adams (1964) and Bock (1989) found no evidence of virus survival on volunteers during the dry season in Malawi. Eradication of volunteer plants and groundkeepers may not be effective in controlling rosette incidence because aphids have a very wide host range and survive during the off-season on alternative hosts. Intercropping groundnut with bean decreased rosette incidence in Malawi (Farrell, 1976b).

In Zimbabwe and South Africa, groundnut rosette has been virtually eliminated in commercial farming areas by the use of improved cultural practices such as removal of volunteer groundnut plants, early sowing, maintaining optimum plant stands, soil fertility, and insecticide use (Hildebrand, personal communications; Snyman, 1979; Cole, 1985).

\subsubsection{Groundnut streak necrosis disease}

2.2.2.1. Distribution and economic importance. Groundnut streak necrosis (GSND) is occasionally important in the warmer, low altitude areas of Malawi, especially in late sown crops. The disease occurs in other countries of the region, but is not regarded as economically important. GSND is caused by sunflower yellow blotch virus (SYBV) and is transmitted by Aphis gossypii Glover. Potential yield loss can be as high as $70 \%$ in early infected plants (Bock, 1989).

2.2.2.2. Management. The incidence of GSND was found to be higher in late-planted groundnut crops $(6.9 \%)$ than in early- 
planted groundnuts $(0.6 \%)$ in Malawi. The virus and its vector persist on Tridax procumbens during the off-season. Intercropping groundnut with sunflower and cultivation of groundnut in cotton growing areas may increase the incidence of GSND on groundnut. There is no evidence of spread of GSND from plant to plant within groundnuts. Although genotypic differences to disease reaction were observed (Bock, 1989), no serious attempts were made in utilization of host-plant resistance to GSND.

\subsection{Nematode disease}

\subsubsection{Pod nematode}

2.3.1.1. Distribution and economic importance. South Africa is the only country in the region where groundnut production is severely affected by the pod nematode Ditylenchus africanus. The identity of the nematode was established in 1988 (De Waele et al., 1988) and the epidemiology has been described (Venter et al., 1991, 1993). The nematode causes losses under both dry and irrigated conditions. Severity is highly variable and results in a downgrading of the produce.
2.3.1.2. Management Ditylenchus suppressive soils have been recognized in the Northern Cape Province of South Africa in fields where groundnuts have been grown for more than 15 years. Such soils harbour large numbers of nematophagous fungi of which 10 genera have been recorded (Jones et al., 1995). Harvesting at normal maturity is very beneficial. Nematicide use has been evaluated (McDonald and van der Berg, 1991) and aldicarb, phenamiphos and oxamil are widely used with excellent control of the disease under irrigated conditions. Under rainfed conditions, a split application of aldicarb has recently been recommended. In South Africa, cultivar Kwarts was released for cultivation in areas where pod nematode is serious (van der Merwe and Joubert, 1995).

\subsubsection{Pod scab nematode}

2.3.2.1. Distribution and economic importance. In the late 1970s, a scab-like dark brown discoloration of groundnut pods was recognized in a field in the Orange Free State area of South Africa (Swanevelder, unpublished). The disease has recently been associated with Tylenchorhynchus brevilineatus (Venter et

Table 3. Options available for the management of various groundnut diseases in the SADC region (from Subrahmanyam and Hildebrand, 1994)

\begin{tabular}{|c|c|c|}
\hline Management options & Major disease(s) controlled & Remarks \\
\hline \multicolumn{3}{|l|}{ Pre-sowing } \\
\hline 1. Crop rotation & $\begin{array}{l}\text { Early and late leaf spots, web blotch, pod rots, seedling diseases, } \\
\text { bacterial wilt, nematode diseases }\end{array}$ & $\begin{array}{l}\text { Highly effective against various diseases. } \\
\qquad \text { Improves soil fertility }\end{array}$ \\
\hline $\begin{array}{l}\text { 2. Break between } \\
\text { successive crops }\end{array}$ & Rust & Eliminate or reduce viable inoculum \\
\hline $\begin{array}{l}\text { 3. Removal of volunteer } \\
\text { groundnut plants }\end{array}$ & Early and late leaf spots, rust, web blotch, rosette & $\begin{array}{l}\text { May not be important in some countries } \\
\text { because of grazing }\end{array}$ \\
\hline $\begin{array}{l}\text { 4. Removal of infected } \\
\text { crop residues }\end{array}$ & Early and late leaf spots, web blotch & $\begin{array}{l}\text { Cumbersome practice; may not be very } \\
\text { effective }\end{array}$ \\
\hline $\begin{array}{l}\text { 5. Deep plowing to bury } \\
\text { infected crop residues }\end{array}$ & Early and late leaf spots, web blotch, stem rot, pod rots, charcoal rot & Suitable under mechanization \\
\hline 6. Good drainage & Root and pod rots, bacterial wilt & $\begin{array}{l}\text { Water logging intensifies disease } \\
\text { incidence }\end{array}$ \\
\hline \multicolumn{3}{|l|}{ At sowing } \\
\hline $\begin{array}{l}\text { 1. Selection of good } \\
\text { quality seed }\end{array}$ & Seedling diseases & $\begin{array}{l}\text { Handpicking of undamaged, matured, } \\
\text { non-mouldy seed }\end{array}$ \\
\hline 2. Seed dressing & Seedling diseases & Treatment with suitable fungicides \\
\hline 3. Optimum depth & Seedling diseases & $\begin{array}{l}\text { Etiolated seedlings are vulnerable to } \\
\text { infection }\end{array}$ \\
\hline 4. Early sowing & Early and late leaf spots, rust, rosette & $\begin{array}{l}\text { Highly effective in reducing disease } \\
\text { incidence/severity }\end{array}$ \\
\hline 5. Intercropping & Early and late leaf spots, rust & Effectiveness varies between locations \\
\hline 6. Varietal mixture & Late leaf spot, possibly other foliar diseases & $\begin{array}{l}\text { May not be suitable when the produce is to } \\
\text { be sold in commercial markets }\end{array}$ \\
\hline \multicolumn{3}{|l|}{ Post-sowing } \\
\hline 1. Optimum plant density & Rosette & $\begin{array}{l}\text { Possible to achieve with selection of good } \\
\text { quality seed, seed dressing, and sowing at } \\
\text { optimum depth }\end{array}$ \\
\hline 2. One spray of fungicide & Early and late leaf spots & $\begin{array}{l}\text { Effective and economical; but chemical } \\
\text { and sprayers may not be available }\end{array}$ \\
\hline 3. Resistant genotypes & $\begin{array}{l}\text { Early and late leaf spots, rust, web blotch, rosette, aflatoxin } \\
\text { contamination }\end{array}$ & $\begin{array}{l}\text { High-yielding genotypes resistant to these } \\
\text { diseases are available }\end{array}$ \\
\hline $\begin{array}{l}\text { 4. Harvesting at optimum } \\
\text { maturity }\end{array}$ & Pod rots, aflatoxin contamination & $\begin{array}{l}\text { Reduces the incidence of pod rots and } \\
\text { aflatoxin contamination }\end{array}$ \\
\hline 5. Rapid drying & aflatoxin contamination & Sun drying \\
\hline 6. Proper storage & concealed damage, seed moulds, aflatoxin contamination & $\begin{array}{l}\text { Storage under damp-proof insect-free } \\
\text { conditions }\end{array}$ \\
\hline
\end{tabular}


al., 1995) and is therefore similar to 'Kalahasti malady' reported from India (Reddy et al., 1984). The disease has recently spread to some fields in the Northern Province and the Vaalharts irrigation area. The cultivar Harts is particularly susceptible to this disease and heavy losses have been recorded (van Wyk, unpublished). This cultivar is widely grown in this area because of its resistance to black hull.

2.3.2.2. Management. Several genotypes have shown resistance to pod scab. The cultivar Selmani is tolerant to the disease (Muller et al., 1995). Nematicides effective against pod nematode are also effective against pod scab nematode and have improved the total yield of cultivar Harts from $0.8 \mathrm{tha}^{-1}$ to $3.2 \mathrm{t} \mathrm{ha}^{-1}$ on a heavily infested soil under irrigation (van Wyk, unpublished).

\section{Integrated disease management}

The effective management of diseases is important if stability and sustainability of groundnut production is to be achieved in the SADC region. Integrated disease management (IDM) is believed to be the most productive, equitable, stable, sustainable, and environment-friendly means to that end. It involves several components: resistant genotypes, cultural practices, and the judicious use of chemicals - which, when used in combination, should prove highly effective in reducing disease severity and contribute to increased productivity (Subrahmanyam and Hildebrand, 1994).

The relative emphasis on the use of various IDM components varies with the disease. For instance, seedling diseases can easily be controlled by using good-quality seed treated with a suitable chemical before sowing; host-plant resistance is less of a priority. Rosette can be controlled using resistant genotypes sown early at optimum population densities.

Considerable research effort has already been directed at chemical control of foliar diseases. Chemical control is economical and very effective in optimum rainfall situations or under irrigated conditions. However, a large number of sprays may be needed to achieve satisfactory disease control and this would not be economically feasible for resource-poor smallholder farmers in rainfed production systems. Chemical control using a large number of sprays is likely to lead to negative returns in drought years (Subrahmanyam and Hildebrand, unpublished), with serious economic and sociological consequences. The cost and availability of chemicals and sprayers, and the risk of yield reduction associated with moisture stress in rainfed systems, have discouraged farmers from investing in chemical control. The indiscriminate use of chemicals leads to serious health and environmental hazards and repeated applications of certain chemicals may result in the evolution of fungicide-tolerant pathogen strains. In recent years, however, research conducted by the SADC/ICRISAT Groundnut Project and by the NARS in Zambia has shown that groundnut foliar diseases can be adequately controlled using a single application of a suitable chemical.

Cultural practices such as crop rotation and early sowing can greatly reduce the severity of foliar diseases. However, these simple cultural practices remain largely non-implemented in the region due to sowing sequences, differential crop priorities and limited land holdings. Groundnut is accorded relatively low priority in the sowing sequence in many countries in the region.
The development of genotypes with resistance to major diseases, and the dissemination of these genotypes to farmers for cultivation, is probably the most effective long-term solution. Groundnut genotypes with resistance to early and late leaf spots, rust, rosette (both long- and short-duration genotypes) and aflatoxin contamination are already available at the SADC/ ICRISAT Groundnut Project for regional evaluation.

The options available for the management of various diseases are listed in Table 3.

\section{Future research needs}

We have identified the following future research needs.

- The occurrence and distribution of various diseases of groundnut need to be determined through systematic surveys in the region. The available information on groundnut diseases and pests from Angola, Botswana, Lesotho, Mozambique and Namibia is inadequate.

- The role of various environmental factors on early leaf spot development, and the occurrence and distribution of pathotypes of the early leaf spot pathogen, need to be determined.

- Identification of sources of stable resistance to early leaf spot and their utilization in breeding programs should be given high priority.

- The occurrence and severity of groundnut rosette in the SADC region fluctuates considerably and the reasons for these fluctuatons should be understood. Serological techniques for detecting groundnut rosette viruses are necessary to undertake studies on disease epidemiology.

- The levels of aflatoxin contamination in various countries in the region need to be determined. The status of soil pests in relation to aflatoxin contamination needs elucidation. There is need to educate farmers in simple agronomic and cultural practices that are effective in reducing aflatoxin contamination.

\section{References}

BABU, S. C., SUBRAHMANYAM, P. and N'GONGOLA, D., 1994. Economic analysis of yield losses due to diseases: a case study of early leaf spot of groundnut in Malawi. African Crop Science Journal, 3, 105-115.

BOCK, K. R., 1987. Rosette and early leaf spot diseases: a review of research progress, 1984/85. In K. R. Bock, D. L. Cole, J. A. Wightman and S. N. Nigam (eds) Proceedings of the Second Regional Groundnut Workshop for Southern Africa, 10-14 February 1986, Harare, Zimbabwe. (Patancheru, Andhra Pradesh 502 324, India: International Crops Research Institute for the Semi-Arid Tropics), pp. 5-14.

BOCK, K. R., 1989. ICR ISAT regional groundnutpathology program: a review of research progress during 1985-87 with special reference to groundnut streak necrosis disease. In K. R. Bock, D. L. Cole, G. L. Hildebrand, S. N. Nigam and J. A. Wightman (eds) Proceedings of the Third Regional Groundnut Workshop for Sourthern Africa, 13 - 18 March 1988, Lilongwe, Malawi (Patancheru, Andhra Pradesh 502 324, India: International Crops Research Institute for the Semi-Arid Tropics), pp. 13-20.

CHITEKA, A. Z., 1984. Report of results of the groundnut breeding and screening for resistance to Phoma and other leafspot diseases on long season varieties. Crop Breeding Institute, Department of Research and Specialist Services, Harare, Zimbabwe. 
CHITEKA, A. Z., 1990. Resistance to botrytis gray mold in some groundnut genotypes in Zimbabwe. In G. L. Hildebrand, G. Schmidt, L. Singh, P. Subrahmanyam, and J. A. Wightman (eds) Proceedings of the Fourth Regional Groundnut Workshop for Southern Africa, 19- 23 March 1990, Arusha, Tanzania (Patancheru, Andhra Pradesh 502 324, India: International Crops Research Institute for the Semi-Arid Tropics), pp. 105- 109.

CHITEKA, Z. A., COLE, D. L., FREIRE, M. J., MAMBA, Z. I., MANDE, H. K., MARAIS, D. J. M., MAYEUX, A., MOIMA, S. S., MMENDA, F. F., RAO, Y. P., SIBUGA, K. P., SYAMASONTA, M. B., SCHMIDT, G., HILDEBRAND G. L. and SUBRAHMANYAM, P., 1992. Groundnut research in the SADCC Region, 1980-1990. In S. N. Nigam (ed) Proceedings of an International Workshop, 25 - 29 November 1991, ICRISAT Center, India (Patancheru, Andhra Pradesh 502 324, India: International Crops Research Institute for the Semi-Arid Tropics), pp. 113-129.

CHIYEMBEKEZA, A. J., SUBRAHMANYAM, P. and HILDEBRAND, G. L., 1996. Identification and on-farm evaluation of rosette-resistant groundnut genotypes in Malawi. In Summary and Recommendations of a Meeting of International Working Group on Groundnut Virus Diseases in Africa, 18 19 March 1996, Plant Protection Research Institute, Pretoria, South Africa (Patancheru 502 324, Andhra Pradesh, India: International Crops Research Institute for the Semi-Arid Tropics) (in press).

COLE, D. L., 1981. Diseases of groundnuts (Arachis hypogaea L.). 1. Fungicide spray effects on Cercospora arachidicola and Phoma arachidicola leaf infection, kernel yield and pod rots. Zimbabwe Journal of Agricultural Research, 19, $101-110$

COLE, D. L., 1985. Pests, diseases and weeds in groundnuts in Zimbabwe. In D. McDonald (ed) Proceedings of the Regional Groundnut Workshop for Southern Africa, 26-29 March 1984, Lilongwe, Malawi (Patancheru, Andhra Pradesh 502 324, India: International Crops Research Institute for the Semi-Arid Tropics), pp. $121-124$

COLE, D. L., 1986. Disease control in groundnuts. The Farmer, 56, 10

COLE, D. L., 1987. Rust disease of groundnut in southern Africa: present situation and possible interactions with other groundnut foliar diseases. In D. McDonald, P. Subrahmanyamand J. A. Wightman (eds) Groundnutrust disease. Proceedings of a Discussion Group Meeting, 24- 28 September 1984 (Patancheru, Andhra Pradesh 502 324, India: International Crops Research Institute for the Semi-Arid Tropics), pp. $109-114$

COLE, D. L., 1991. The prevalence of aflatoxins in groundnuts in Zimbabwe. In Proceedings of the Second Regional Groundnut Plant Protection Group Tour, Zimbabwe, Mozambique, Swaziland, 25 February- 1 March 1991, Lilongwe, Malawi: SADCC/ICRISAT Groundnut Project, P.O. Box 1096, Lilongwe, Malawi (Patancheru, Andhra Pradesh 502 324, India: International Crops Research Institute for the Semi-Arid Tropics), pp. 56-61.

COLE, D. L. and CHINGOMBE, P. T., 1981. Diseases of groundnut (Arachis hypogaea L.) 2. Comparison of four sprays for the control of Cercospora arachidicola and Phoma arachidicola on groundnuts. Zimbabwe Journal of Agricultural Research, 19, 163-169.

COLE, D. L. and MASUKA, A. J., 1988. Evaluation of new rapid methods for aflatoxin detection in groundnuts in Zimbabwe. In K. R. Bock, D. L. Cole, G. L. Hildebrand, S. N. Nigam and J. A. Wightman (eds) Proceedings of the Third Regional Groundnut Workshop for Southern Africa 13-18 March 1988, Lilongwe, Malawi (Patancheru, Andhra Pradesh 502 324, India: International Crops Research Institute for the Semi-Arid Tropics), pp. $185-189$.

DAVIES, J. C., 1976. The incidence of rosette disease in groundnut in relation to plant density and its effect on yield. Annals of Applied Biology, 82, 489501.

DE WAELE, D., JONES, B. L. and BOLTON, C., 1988. First report of Ditylenchus destructor in pods and seeds of groundnuts. Phytophylactica, $20,108$.

DU TOIT, A. A., 1977. Aflatoxin research in Rhodesia. Rhodesian Agricultural Journal, Research Report No. 1, p. 33

FARRELL, J. A. K., 1976a. Effects of groundnut sowing date and plant spacing on rosette virus disease in Malawi. Bulletin of EntomologicalResearch, 66, $159-171$.

FARRELL, J. A. K., 1976b. Effects of intersowing with bean on the spread of groundnut rosette virus by Aphis craccivora Koch (Hemiptera, Aphididae) in Malawi. Bulletin of Entomological Research, 66, $331-333$.

FARRELL, J. A. K. and ADAMS, A. N., 1964. Annual Report (Agricultural Research Council, Malawi, Central Africa), p. 32.
FARRELL, J. A. K., BAILEY, B. E. and MILLS, W. R., 1967. The effects of time of planting, spacing and fungicides on Cercospora leaf spots of groundnut in Malawi. Rhodesia, Zambia, Malawi Journal of Agricultural Research, 5, $241-247$

GIBBONS, R. W., FARRELL, J. A. K. and ADAMS, A. N., 1966. Peanut rosette virus disease in Central Africa. Proceedings of the IVth National Peanut Research Conference, $14-15$ July 1966, University of Georgia, Athens, Georgia, USA.

HEMMINGWAY, J. S., 1954. Cercospora leafspots of groundnuts in Tanganyika. East African Agriculture Journal, 19, 263 - 271.

HILDEBRAND, G. L., 1975. Groundnut variety improvement in Rhodesia. Paper presented at the Workshop on Germplasm Preservation and Genotype Evaluation in Peanuts, 12 - 15 July 1975, University of Florida, Gainesville, Florida, USA.

HILDEBRAND, G. L., 1981. Further use of introduced groundnut (Arachis hypogaea L.) germplasm in Zimbabwe. Paper presented at ICRISAT Center, Patancheru, Andhra Pradesh 502 324, India, p 11.

HILDEBRAND, G. L., 1983. Groundnuts: effects of fungicide application on different genotypes. Report on Research Results (Harare, Zimbabwe: Commercial Oilseeds Producers Association).

HILDEBRAND, G. L., 1984. GroundnutResearch: Report of Results for 1983/84 Season (Harare, Zimbabwe: Commercial Oilseeds Producers Association).

HILDEBRAND, G. L., 1985. GroundnutResearch: Report of Results for 1984/85 Season (Harare, Zimbabwe: Commercial Oilseeds Producers Association).

HILDEBRAND, G. L., 1987. Genotype Xenvironment interaction in long- and short-season groundnut (Arachis hypogaea L.) genotypes to infection by Cercospora arachidicola and Didymella arachidicola, DPhil thesis, University of Zimbabwe, Harare, Zimbabwe, pp. 220.

HILDEBRAND, G. L. and BOCK, K. R., 1990. Effect of timing of single applications of fungicide on groundnut yield. In G. L. Hildebrand, G. Schmidt, L. Singh, P. Subrahmanyam and J. A. Wightman (eds) Proceedings of the Fourth Regional Groundnut Workshop for Southern Africa, 19-23 March 1990, Arusha, Tanzania (Patancheru, Andhra Pradesh 502 324, India: International Crops Research Institute for the Semi-Arid Tropics), pp. 3-7.

JONES, B. L., JOOSTE, W. J. and SWART, A., 1995. Survey of nematophagous fungi in groundnut soils in South Africa. African Plant Protection, 2, $51-58$.

KANNAIYAN, J., SANDHU, R. S. and HACIWA, H. C., 1987. Recent developments in groundnut pathology research in Zambia. In K. R. Bock, D. L. Cole, J. A. Wightman and S. N. Nigam (eds) Proceedings of the Second Regional Groundnut Workshop for Southern Africa, 10-14 February 1986, Harare, Zimbabwe (Patancheru, Andhra Pradesh 502 324, India: International Crops Research Institute for the Semi-Arid Tropics), pp. $51-56$.

KANNAIYAN, J., SANDHU, R. S., HACIWA, H. C. and REDDY, M. S., 1989a. Management of leaf spots of groundnut in Zambia. In K. R. Bock, D. L. Cole, G. L. Hildebrand, S. N. Nigam and J. A. Wightman (eds) Proceedings of the Third Regional Groundnut Workshop for Southern Africa, 13-18 March 1988, Lilongwe, Malawi (Patancheru, Andhra Pradesh 502324 , India: International Crops Research Institute for the Semi-Arid Tropics), pp. $35-41$.

KANNAIYAN, J., SANDHU, R. S. and PHIRI, A. L., 1989b. Aflatoxin and Aspergillus flavus contamination problems of groundnut in Zambia. In D. McDonald and V. K. Mehan (eds) Aflatoxin contamination of groundnut: Proceedings of the International Workshop, 6-9 October 1987 (Patancheru, Andhra Pradesh 502 324, India: International Crops Research Institute for the Semi-Arid Tropics), pp. 65-70.

KELLY, G., 1985. A review of agronomic work in Zambia, and prospects for the future. In D. McDonald (eds) Proceedings of the Regional Groundnut Workshop for Southern Africa, 26-29 March 1984, Lilongwe, Malawi (Patancheru, Andhra Pradesh 502 324, India: International Crops Research Institute for the Semi-Arid Tropics), pp. $115-118$.

KISYOMBE, C. T., 1980. Daconil 2787 W-75 trials on groundnuts in the 1979/80 season. Progress Report, Chitedze Agricultural Research Station, PO Box 158, Lilongwe, Malawi, p. 9. 
KISYOMBE, C. T., 1987a. Ecology of groundnut diseases of major and minor importance in Malawi. In Proceedings of a Regional Groundnut Plant Protection Group Meeting, 16-20 February 1987, Harare, Zimbabwe (Patancheru, Andhra Pradesh 502 324, India: International Crops Research Institute for the Semi-Arid Tropics), pp. 53-56.

KISYOMBE, C. T., 1987b. Epidemiology of foliar fungal diseases and their control with fungicides in the 1984/85 season. In K. R. Bock, D. L. Cole, J. A. Wightman and S. N. Nigam (eds) Proceedings of the Second Regional Groundnut Workshop for Southern Africa, 10-14 Feb 1986, Harare, Zimbabwe (Patancheru, Andhra Pradesh 502 324, India: International Crops Research Institute for the Semi-Arid Tropics), pp. $139-142$.

KISYOMBE, C. T., 1989. Aflatoxin contamination of groundnuts: control strategies in Malawi. In D. McDonald and V. K. Mehan (eds) Aflatoxin Contamination of Groundnut: Proceedings of the International Workshop, 6-9 October 1987 (Patancheru, Andhra Pradesh 502 324, India: International Crops Research Institute for the Semi-Arid Tropics), pp. $71-76$.

KLOPPERS, F. J. and LABUSCHAGNE, C. L. E., 1989. Blaarvleksiektes by grondbone. Deel 2. Spatselvlek. Oil Seeds News, March, 18-20.

LABUSCHAGNE, C. L. E. and KLOPPERS, F. J., 1988. Blaarvleksiektes by grondbone. Deel 1. Vroee- en laat blaarvlek. Oil Seeds News, December, $15-17$.

LABUSCHAGNE, C. L. E., STRAUSS, F. M. and JANSEN, W. J., 1990. Die chemiese beheer van die blaarsiektekompleks, asook Botrytis stamvrot by grondbone. Oil Seeds News December, 7-13.

LYIMO, H. J. and KANGALAWE, R. Y. M., 1991. The effect of groundnut cultivar mixtures, intercropping, and date of planting on severity of late leaf spot. In Proceedings of the Second Regional Groundnut Plant Protection Group Tour, Zimbabwe, Mozambique, and Swaziland, 25 February- 1 March 1991. SADCC/ICRISAT Groundnut Project, PO Box 1096, Lilongwe, Malawi (Patancheru, Andhra Pradesh 502 324, India: International Crops Research Institute for the Semi-Arid Tropics), pp. $91-95$

MAYEUX, A. and MAPHANYANE, G. S., 1989. Groundnut research under low-rainfall conditions in Botswana. In K. R. Bock, D. L. Cole, G. L. Hildebrand, S. N. Nigam and J. A. Wightman (eds) Proceedings of the Third Regional Groundnut Workshop for Southern Africa, 13-18 Mar 1988, Lilongwe, Malawi (Patancheru, Andhra Pradesh 502 324, India: International Crops Research Institute for the Semi-Arid Tropics), pp. $149-155$.

McDONALD, D., 1989. The ICRISAT approach to research on the groundnut aflatoxin problem. In D. McDonald and V. K. Mehan (eds) Aflatoxin Contamination of Groundnut: Proceedings of the International Workshop, 6-9 October 1987 (Patancheru, Andhra Pradesh 502 324, India: International Crops Research Institute for the Semi-Arid Tropics), pp. $317-321$.

McDONALD, A. H. and VAN DER BERG, E. H., 1991. Evaluation of nematicides for the control of Ditylenchus destructor in groundnut fields. Phytophylactica, 21, 108.

MEHAN, V. K., 1987. The aflatoxin contamination problem in groundnut: control with emphasis on host-plant resistance. In Proceedings of the First Regional Groundnut Plant Protection Group Meeting, 15-21 February 1987, Harare, Zimbabwe, ICRISAT Regional Groundnut Improvement Programme for Southern Africa, Lilongwe, Malawi (Patancheru, Andhra Pradesh 502 324, India: International Crops Research Institute for the Semi-Arid Tropics), pp. $63-92$.

MERCER, P. C., 1974. Fungicidal control of leafspots of groundnut in Malawi. Oleagineux, 29, $247-252$.

MERCER, P. C., 1978. Pests and diseases of groundnuts in Malawi. II. Disorders of pods, kernels and seedlings. Oleagineux, 33, 119-122.

MERCER, P. C. and KISYOMBE, C. T., 1978. The fungal flora of groundnut kernels in Malawi and the effect of seed dressing. PANS (Pest Articles and News Summaries), 24, 35- 42.

MPIRI, M. G., 1991. Progress of groundnutcrop protection work in the Tanzania Oilseeds Project. In Proceedings of the Second Regional GroundnutPlant Protection Group Tour, Zimbabwe, Mozambique, and Swaziland, 25 February- 1 March 1991, SADCC/ICRISAT Groundnut Project, PO Box 1096, Lilongwe, Malawi (Patancheru, Andhra Pradesh 502 324, India: International Crops Research Institute for the Semi-Arid Tropics), pp. 96 105.
MUGHOGHO, L. K., 1969. Mycosphaerella leafspot disease of groundnuts in Malawi. Paper presented at the Third East African Cereals Research Conference, Zambia and Malawi, March 1969.

MULLER, T., VAN DER MERWE, P. J. A. and CILLIER, A., 1995. Groundnut cultivars for protein production. Research Report 1994/95, South Africa: Protein Research Trust.

MMENDA, A. R. E. and CUSACK, T. J., 1989. An economic evaluation of smallholder farmers' use of the fungicide chlorothalonil (Daconil ${ }^{R} 2787 \mathrm{~W}$ 75) on groundnuts in Lilongwe Agricultural DevelopmentDivision, Malawi. In K. R. Bock, D. L. Cole, G. L. Hildebrand, S. N. Nigam and J. A. Wightman (eds) Proceedings of the Third Regional Groundnut Workshop for Southern Africa, 13-18 March 1988, Lilongwe, Malawi (Patancheru, Andhra Pradesh 502 324, India: International Crops Research Institute for the Semi-Arid Tropics), pp. 65-73.

NGWIRA, P., 1985. Groundnut improvement in Malawi. In D. McDonald (eds) Proceedings of the Regional Groundnut Workshop for Southern Africa, 26 - 29 March 1984, Lilongwe, Malawi (Patancheru, Andhra Pradesh 502 324, India: International Crops Research Institute for the Semi-Arid Tropics), pp. $49-53$.

NIGAM, S. N. and BOCK, K. R., 1985. A regional approach to groundnut improvement. In D. McDonald (eds) Proceedings of the Regional Groundnut Workshop for Southern Africa, 26- 29 March 1984, Lilongwe, Malawi (Patancheru, Andhra Pradesh 502 324, India: International Crops Research Institute for the Semi-Arid Tropics), pp. 33-42.

PAUER, G. D. C., 1979. Swamdoders en die beheer van blaarvleksiektes van grondbone. Oil Seeds News, December, 22- 23.

RAMANAIAH, K. V., FREIRE, M. J., CHILENGUE, B. S. and MUNGUAMBE, A. V., 1989. Research on groundnuts in Mozambique. In K. R. Bock, D. L. Cole, G. L. Hildebrand, S. N. Nigam and J. A. Wightman (eds) Proceedings of the Third Regional Groundnut Workshop for Southern Africa, 13-18 March 1988, Lilongwe, Malawi (Patancheru, Andhra Pradesh 502324 , India: International Crops Research Institute for the Semi-Arid Tropics), pp. $157-161$

RAO, Y. P. and MASINA, G. T., 1987. Groundnut production and research in Swaziland. In K. R. Bock, D. L. Cole, J. A. Wightman and S. N. Nigam (eds) Proceedings of the Second Regional Groundnut Workshop for Southern Africa, 10-14 February 1986, Harare, Zimbabwe (Patancheru, Andhra Pradesh 502 324, India: International Crops Research Institute for the Semi-Arid Tropics), pp. 73-76.

REDDY, D. D. R., SUBRAHMANYAM, P., SANKARA REDDY, G. H., RAJA REDDY and SIVA RAO, D. V., 1984. A nematode disease of peanut caused by Tylenchorhynchus brevilineatus: Plant Disease, 68, 526- 529.

REDDY, D. V. R., MURANT, A. F., DUNCAN, G. H., ANSA, O. A., DEMSKI, J. W. and KUHN, C. W., 1985. Viruses associated with chlorotic rosette and green rosette diseases of groundnut in Nigeria. Annals of Applied Biology, $107,57-64$.

REDDY, D. V. R., 1984. Groundnut rosette. In D. M. Porter, D. H. Smith and R. Rodriguez-Kabana (eds) Compendium of Peanut Diseases (St Paul, Minnesota, USA: American Phytopathological Society), pp. 49-50.

REDDY, L. J., SUBRAHMANYAM, P., CHIYEMBEKEZA, A. J., HILDEBRAND, G. L., NIGAM, S. N. and McDONALD, D., 1996. Exploitation of host-plant resistance for the management of rust and late leaf spot of groundnut. In Proceedings of the Second Crop Science Conference for Eastern and Southern Africa, 19 - 24 February 1995, Blantyre, Malwai (in press).

ROTHWELL, A., 1962. Diseases of groundnuts in Southern Rhodesia. Rhodesian Agricultural Journal, 59, 199- 201.

ROTHWELL, A., 1975. Peanut rust in Rhodesia. Plant Disease Reporter, 59, $802-803$

SANDHU, R. S., KELLY, G. and KANNAIYAN, J., 1985. Groundnut production and research: Problems and priorities in Zambia. In D. McDonald (ed) Proceedings of the Regional Groundnut Workshop for Southern Africa, 26 - 29 March 1984, Lilongwe, Malawi (Patancheru, Andhra Pradesh 502 324, India: International Crops Research Institute for the Semi-Arid Tropics), pp. $107-113$.

SIMONS, J. H., 1985. Groundnut crop protection work in the Tanzania oilseeds research project. In D. McDonald (ed) Proceedings of the Regional Groundnut Workshop for Southern Africa, 26- 29 March 1984, Lilongwe, Malawi (Patancheru, Andhra Pradesh 502 324, India: International Crops Research Institute for the Semi-Arid Tropics), pp. $93-97$. 
SNYMAN, J. W., 1979. Rosette by grondbone. Oil Seeds News, December, 8. STRAUSS, F. M. and VAN WYK, P. S., 1995. Swamdoders vir die beheer van Botrytis cinerea op grondbone, (Stellenbosch, South Africa: 23 South African Society for Crop Production.

SUBRAHMANYAM, P., 1983. Report on an assignment to study diseases of groundnut in Malawi. Groundnut Improvement Program, Miscellaneous Publication (Patancheru, Andhra Pradesh 502 324, India: International Crops Research Institute for the Semi-Arid Tropics), $161 \mathrm{pp}$.

SUBRAHMANYAM, P., 1991. Diseases of groundnut in the SADCC region. In Proceedings of the First Steering Committee Meeting, 16-17 April 1991, SADCC/ICRISAT Groundnut Project, PO Box 1096, Lilongwe, Malawi (Patancheru, Andhra Pradesh 502 324, India: International Crops Research Institute for the Semi-Arid Tropics), pp. 14-17.

SUBRAHMANYAM, P. and HILDEBRAND, G. L., 1994. Integrated disease management: an important component in sustaining groundnut production in the SADC Region. In B. J. Ndunguru, G. L. Hildebrand and P. Subrahmanyam (eds) Proceedings of the Sixth Regional Groundnut Workshop for Southern and Eastern Africa, 5-7 Jul 1994, Mbabane, Swaziland (Patancheru 502 324, Andhra Pradesh, India: International Crops Research Institute for the Semi-Arid Tropics), pp. 45-50.

SUBRAHMANYAM, P. and MCDONALD, D., 1983. Rust disease of groundnut. Information Bulletin no. 13 (Patancheru, Andhra Pradesh 502 324, India: International Crops Research Institute for the Semi-Arid Tropics), 20 pp.

SUBRAHMANYAM, P., RAMANATHARAO, V., MCDONALD, D., MOSS, J. P. and GIBBONS, R. W., 1989. Origins of resistances to rust and late leaf spot in peanut (Arachis hypogaea, Fabaceae). Economic Botany, 43, $444-455$.

SUBRAHMANYAM, P., HILDEBRAND, G. L. and NDUNGURU, B. J., 1994a. Integrated managementof early leaf spot of groundnut in the SADC region. In Proceedings of the First Crop Science Conference for Eastern and Southern Africa, 14-18 June 1993, African Crop Science Society, Kampala, Uganda, pp. 244- 248.

SUBRAHMANYAM, P., HILDEBRAND, G. L., TABER, R. A., COLE, D. L., SMITH, D. H. and McDONALD, D., 1994b. Web blotch disease of groundnut ICRISAT Information Bulletin 43 (Patancheru 502 324, Andhra Pradesh, India: International Crops Research Institute for the Semi-Arid Tropics and Griffin, GA 30223, USA: Peanut Collaborative Research Support Programme, pp. 20.
SUBRAHMANYAM, P., REDDY, L. J. and SINGH, A. K., 1996. Recent progress in screening of global germplasm and identification of new sources of resistance to groundnut rosette disease. In Summary and Recommendations of a Meeting of International Working Group on Groundnut Virus Diseases in Africa, 18-19 March 1996, Plant Protection Research Institute, Pretoria, South Africa (Patancheru 502 324, Andhra Pradesh, India: International Crops Research Institute for the Semi-Arid Tropics) (in press).

SWANEVELDER, C. J., 1985. Rust on groundnuts on the Highveld. Oil Seeds News, June, 17.

SWANEVELDER, C. J., 1988. Blaarvlekbeheer ja of nee? Oil Seeds News, December, $26-27$.

VAN DER MERWE, P. J. A. and JOUBERT, H., 1995. New groundnut cultivars for South Africa Information Bulletin (Potchefstroom, South Africa: Agricultural Research Council, Grin Crops Institute).

VAN DER MERWE, P. J. A. and SWANEVELDER, C. J., 1988a. Harts: a pod rot-resistant groundnut. Farming in South Africa, Circular C2 (South Africa: Department of Agriculture and Water Supply).

VAN DER MERWE, P. J. A. and SWANEVELDER, C. J., 1988b. Norden: a new groundnut. Farming in South Africa, Circular C3 (South Africa: Department of Agriculture and Water Supply).

VENTER, C., DE WAELE, D. and MEYER, A. J., 1991. Effect of early and late harvesting on the economic damage caused by Ditylenchus destructor to peanut in South Africa. Journal of Nematology, 23, 554.

VENTER, C., DE WAELE, D. and MEYER, A. J., 1993. Reproductive and damage potential of Ditylenchus destructor on six peanut cultivars. Journal of Nematology, 25, $59-62$.

VENTER, C., STEENKAMP AND VAN WYK, P. S., 1995. The role of Tylenchorhynchus brevilineatus in scab of groundnut. 12th Symposium of the Nematological Society of South Africa, Karos Lodge, Kruger Gate, March 1995. African Plant Protection, 2, 83. 
Copyright $\odot 2002$ EBSCO Publishing 